APPLIGATIONS OF MORAL PHILOSOPHY 
New Studies in Practical Philosophy

General Editor: W. D. Hudson

The point of view of this series is that of contemporary analytical philosophy. Each study will deal with an aspect of moral philosophy. Particular attention will be paid to the logic of moral discourse, and the practical problems of morality. The relationship between morality and other 'universes of discourse', such as art and science, will also be explored.

\section{Published}

R. W. Beardsmore Art and Morality

R. M. Hare Practical Inferences

R. M. Hare Essays on Philosophical Method

R. M. Hare Essays on the Moral Concepts

R. M. Hare Applications of Moral Philosophy

N. M. L. Nathan The Concept of Justice

Titles in preparation include

A. G. N. Flew Crime or Disease?

Pamela Huby Plato and Modern Morality

E. Kamenka Freudianism and Ethics

T. A. Roberts The Concept of Benevolence 


\title{
APPLICATIONS OF MORAL PHILOSOPHY
}

\author{
R. M. HARE
}

White's Professor of Moral Philosophy in the University of Oxford 
(C) R. M. Hare 1972 except where otherwise stated Softcover reprint of the hardcover 1st edition 1972

All rights reserved. No part of this publication may be reproduced or transmitted, in any form or by any means, without permission.

First published 1972 by

THE MACMILLAN PRESS LTD

London and Basingstoke

Associated companies in New Tork Toronto

Dublin Melbourne Johannesburg and Madras

SBN 333 II42I 3

ISBN 978-1-349-00957-2 ISBN 978-1-349-00955-8 (eBook)

DOI 10.1007/978-1-349-00955-8 


\section{Contents}

Acknowledgements vi

Editor's Foreword vii

Preface ix

I Can I Be Blamed for Obeying Orders? (I955) I

2 Reasons of State (r957) 9

3 Function and Tradition in Architecture (1959) 24

4 'Nothing Matters' (1957) 32

5 Adolescents into Adults (I96I) 48

6 What is Life? (1965) 67

7 Peace (1966) 7I

8 The Lawful Government (1964) 90

9 Community and Communication (I968) 109 


\section{Acknowledgements}

The Listener (Oct. 1955), by permission of the British Broadcasting Corporation. La Philosophie Analytique, Cahiers de Royaumont, no. IV (Editions de Minuit, Paris, I959). T. H. B. Hollins (ed.), Aims in Education (Manchester University Press, 1964). Elseviers Weekblad (1964) and Crucible (r965). Research Students' Association, Australian National University, Canberra. P. Laslett and W. G. Runciman (eds), Philosophy, Politics and Society, III (Blackwell, Oxford, 1967). S. Verney (ed.), People and Cities (Fontana Books, London, 1969). 


\section{Editor's Foreword}

This volume contains studies by an analytical moral philosopher of some practical moral problems. It gives the lie to those who accuse moral philosophers of being no longer interested in real moral issues. It reflects the author's wide range of interests and deep concern about what is happening within our society. All the issues discussed are of vital importance and call for moral choice on the part of all responsible persons. This collection of papers is interesting as an attempt at bridgebuilding between the theoretical concerns of the analytical philosopher and the practical questions which the moralist tries to answer. Can this bridge be built? Has moral philosophy anything to say which is of practical help to us in deciding what we ought to do? Not only philosophers but all intelligent men must find this question important and Professor Hare provides here examples of how it can be answered in the affirmative. 


\section{Preface}

I became a moral philosopher because I was troubled about practical moral questions; and from the time that I took up the subject I have (to help me in my theoretical work and for their own interest) continually done studies of such practical topics, some of which I have printed and some not. I have long wished to publish a collection of these, and am grateful to Dr Hudson and to Macmillan for encouraging me to do so; but by this time the papers available are far too numerous to go into one volume. I have therefore selected those which are in the best shape; the rest, mostly on medical, political or educational problems, will have to wait until I have caught up with their constantly changing subject-matter. None of the pieces here printed was aimed primarily at my philosophical colleagues, and they were written over a period of at least fifteen years; the reader must not, therefore, expect consistency of terminology or even of opinion, and I must warn students against trying by minute textual comparisons with these papers to shed light on the meaning of my more academic writings. Nevertheless the views here presented are grounded on my views in theoretical ethics, and, if allowance is made for some looseness of expression, consistent with them. I have, except for some omissions and minor editorial corrections, printed the papers in the form in which they were first published or broadcast. In the first volume of the set, Practical Inferences, I included a bibliography of my published writings, in which the contents of the other volumes can be discovered. Notes added in this edition are distinguished by asterisks; the original footnotes have numbers. I am grateful to the original publishers, who are identified in the footnotes, for giving their permission to reprint where necessary.

I shall be satisfied if some who read these papers are led to 
think that philosophical thought can help us towards the solution of practical problems, and if a few of these join the increasing number of philosophers who are actually trying to show how it can be done.

Corpus Christi College,

R. M. HARE

Oxford

I97I 